\title{
Community-based Study on Newborn Care Practices and its Determinants in Rural Pondicherry, India
}

Vijayalakshmi S*, Rajkumar Patil and Shib Sekhar Datta

Mahatma Gandhi Medical College and Research Institute, India

\begin{abstract}
Background: Globally, around $86 \%$ of neonatal deaths occurred are due to infections and preterm births. To prevent newborn infection, clean delivery and newborn carepractices should be adopted. Understanding of the community and traditional new-born care practices is necessary to implement the effective programme for promotion of newborns health.
\end{abstract}

Objectives: To study the new-born care practices and its determinants in a rural area of Puducherry, India.

Methodology: A cross sectional study done in Bahour commune from $1^{\text {st }}$ April 2012 to $31^{\text {st }}$ June 2012. Information regarding background details and new-born care practices were recorded in semi-structured questionnaire by house to house visit. Total of 136 infants born during Jan-March 2012 were enrolled. Data were presented as percentages, ratios and Chi-square test was used to find association among variables. $p$-value $<0.05$ was considered statistically significant.

Results: Among 136 newborns, 46.3\% were male and 53.7\% were female. Around $65 \%$ newborns were breastfed within an hour after birth and $5.9 \%$ were prelacteally fed. There was significant difference between male and female newborns in terms of wrapping after birth and day of first bath ( $p$ value 0.04 and 0.007 respectively). Out of 37 mothers who belonged to poor socio-economic status, $24.3 \%$ mothers practiced application on cord with significant association $(p=0.03)$. Majority $(70.6 \%)$ of mothers gave bath to their newborn's on third day or beyond. In the present study, mothers age at marriage and day of first bath to newborn's was significantly associated $(p=0.02)$.

Conclusions: The overall practices like giving pre-lacteal feed; application on umbilical cord and giving bath immediately after bath of newborn are still practiced in the study area. Therefore, faulty newborn care practices need to be addressed.

Keywords: Neonatal mortality rate; Skilled birth attendance; Consanguineous marriage; Nuclear families

\section{Background}

"No investment in global health has a greater return than saving the life of a child. With sufficient resources and political resolve, we can ensure a healthy start, and a promising future, for children everywhere." Melinda Gates, Bill and Melinda Gates Foundation.

Newborn care practices shows the importance given to the wellbeing of the newborn and raising a child well [1]. Newborns are valuable treasure to the nation. Realizing the importance of child development, United Nations declared 1979 as the International Year of the Child [2] and World Health Organisation (WHO) proposed a theme on World health day during 2003 as "Healthy environment for children" and 2005 as "Make every mother and child count" to focus the attention of planners, policy makers, administrators, health and social scientists on various problems faced by children [3].

Neonatal mortality has been declining worldwide. Neonatal Mortality Rate (NMR) is reduced by $28 \%$ in last two decades from an estimated 32 deaths per 1000 live births (year 1990) to 21 deaths (year 2011) [4]. Globally, around $86 \%$ of neonatal deaths are due to pneumonia, diarrhoea, and preterm births. To prevent newborn and maternal infection, clean delivery practices and appropriate treatment should be adopted. Birth asphyxia causes $23 \%$ of newborn deaths and can largely be prevented by improved care during labour and delivery [4].

Social determinants for child mortality include early marriage and childbirth at a very young age, less spacing between births and low literacy level among women, in particular those belonging to the urban poor and rural settings. Under National Rural Health Mission (NRHM), there are a number of focused interventions for improving care of the new-born, which include focus on improving access to Skilled Birth Attendance (SBA) and Emergency Obstetric Care for all women in rural areas. On the demand side, Janani Suraksha Yojana and Janani Shishu Suraksha Karyakram have managed in overcoming many traditional barriers to institutional deliveries [5].

Several programmes have been implemented by Government of India along with WHO and UNICEF to improve the health status of newborns. Many customs are prevalent in India which affects health status of the new-borns. Understanding of the community and traditional newborn care practices is necessary to implement the effective programme for promotion of newborns health. For the effective child health care delivery, information regarding newborn care is important. This study was done to describe selected newborn care practices in rural area of Puducherry.

\section{Aims and Objectives}

1. To study the newborn care practices in a rural area of Puducherry.

*Corresponding author: Vijayalakshmi S, Mahatma Gandhi Medical college and Research Institute, Pondicherry, Puducherry, India, Tel:9788942682; E-mail: vijilakshmi121@gmail.com

Received August 05, 2014; Accepted September 05, 2014; Published September 07, 2014

Citation: Vijayalakshmi S, Patil R, Datta SS (2014) Community-based Study on Newborn Care Practices and its Determinants in Rural Pondicherry, India. $J$ Neonatal Biol 3: 158. doi:10.4172/2167-0897.1000158

Copyright: (C) 2014 Vijayalakshmi S, et al. This is an open-access article distributed under the terms of the Creative Commons Attribution License, which permits unrestricted use, distribution, and reproduction in any medium, provided the original author and source are credited. 
Citation: Vijayalakshmi S, Patil R, Datta SS (2014) Community-based Study on Newborn Care Practices and its Determinants in Rural Pondicherry, India. J Neonatal Biol 3: 158. doi:10.4172/2167-0897.1000158

Pge 2 of 5

2. To find out the determinants of newborn care practices.

\section{Materials and Method}

This was a Community based cross sectional study done in the rural area of Pondicherry. As per convenience, child born to mothers during Jan-March 2012 were enrolled for the study through Anganwadi registers from Bahour Commune during April-June 2012.

Total 136 newborns were included in the study. Information regarding background details and newborn care practices were recorded in semi-structured questionnaire.

The investigator interviewed the mother/husband in local language using a pre-designed proforma. Each infant-mother was interviewed for about 40 minutes. Mothers were informed through phone prior to visit and then house to house visit was done.

\section{Statistical Analysis}

The data was entered and analysed using Microsoft Excel and were presented as percentages and ratios. Chi-square test and Fisher's exact $\mathrm{p}$ test were used to find association between the variables. $\mathrm{p}$-value $<0.05$ was considered as statistically significant.

\section{Results}

Total 136 newborn's mothers participated in the study. Among 136 newborn's, 63(46.3\%) were male and $73(53.7 \%)$ were female.

Table 1 shows the socio-demographic profile of the study newborns in rural Puducherry. Majority of the newborns (94.9\%) belonged to Hindu families. According to modified B.G. Prasad's Classification for socio-economic status [6], 51 (37.5\%) newborns belonged to lowermiddle class followed by $37(27.2 \%)$ newborns in poor class. Total 97 $(71.3 \%)$ mothers were educated up to $12^{\text {th }}$ standard and $18(13.2 \%)$

\begin{tabular}{|l|c|}
\hline Characteristics & $\mathbf{N}(\%)$ \\
\hline Religion & $129(94.9)$ \\
\hline Hindu & $6(4.4)$ \\
\hline Christian & $1(0.7)$ \\
\hline Muslim & $3(2.2)$ \\
\hline Socio-economic status & $18(13.2)$ \\
\hline Upper high & $27(19.9)$ \\
\hline High & $51(37.5)$ \\
\hline Upper middle & $37(27.2)$ \\
\hline Lower middle & $21(15.5)$ \\
\hline Poor & $97(71.3)$ \\
\hline Education level of mother & $18(13.2)$ \\
\hline Illiterate & $8(5.9)$ \\
\hline Upto 12 ${ }^{\text {th }}$ std & $92(67.6)$ \\
\hline Graduate and above & $36(26.5)$ \\
\hline Education level of father & $114(83.8)$ \\
\hline Illiterate & $15(11)$ \\
\hline Upto 12th Std & $7(5.1)$ \\
\hline Graduate and above & \\
\hline Occupation of mother & $1(0.7)$ \\
\hline Housewife & \\
\hline Business/Service & \\
\hline Labourer/Fisherwoman/Farmer & \\
\hline Occupation of father & \\
\hline Labourer/Fisherman/Farmer & \\
\hline Business/Service & \\
\hline Unemployed & \\
\hline
\end{tabular}

Table 1: Socio-demographic profile of study infants $(\mathrm{N}=136)$.

\begin{tabular}{|l|c|}
\hline Characteristics & $\mathbf{N}(\%)$ \\
\hline $\mathrm{H} / \mathrm{O}$ consanguineous marriage & $16(11.8)$ \\
\hline Yes & $120(88.2)$ \\
\hline No & $8(5.9)$ \\
\hline Mothers age at marriage (in years) & $88(64.7)$ \\
\hline$<18$ & $30(22)$ \\
\hline 18 to 22 & $10(7.4)$ \\
\hline 23 to 27 & \\
\hline$\geq 28$ & $73(53.7)$ \\
\hline Type of family & $63(46.3)$ \\
\hline Nuclear & $114(83.8)$ \\
\hline Joint & $22(16.2)$ \\
\hline Number of living children & \\
\hline$\leq 2$ & \\
\hline$>2$ & \\
\hline
\end{tabular}

Table 2: Family background of new-borns $(\mathrm{N}=136)$.

\begin{tabular}{|c|c|c|c|}
\hline Characteristics & $\begin{array}{l}\text { Male } \\
(n=63)\end{array}$ & $\begin{array}{c}\text { Female } \\
(n=73)\end{array}$ & Total \\
\hline \multicolumn{4}{|l|}{ Order of birth } \\
\hline 1 & $28(44.4)$ & $30(51.7)$ & $58(42.6)$ \\
\hline 2 & $24(38.1)$ & $31(56.4)$ & $55(40.4)$ \\
\hline$\geq 3$ & $11(17.5)$ & $12(52.2)$ & $23(17)$ \\
\hline \multicolumn{4}{|l|}{ Birth interval* $(\mathrm{N}=78)$} \\
\hline$\leq 24$ months & $5(14.3)$ & $7(16.3)$ & $12(15.4)$ \\
\hline 25-36 months & $27(77.1)$ & $32(74.4)$ & $59(75.6)$ \\
\hline$>36$ months & $3(8.6)$ & $4(9.3)$ & $7(9)$ \\
\hline \multicolumn{4}{|l|}{ Place of delivery } \\
\hline Home & $1(1.6)$ & 0 & $1(0.7)$ \\
\hline Institutional & $62(98.4)$ & $73(100)$ & $135(99.3)$ \\
\hline \multicolumn{4}{|l|}{ Birth attendant } \\
\hline Doctor/ nurse/ANM & $62(98.4)$ & $73(100)$ & $135(99.3)$ \\
\hline Trained dai & $1(1.6)$ & 0 & $1(0.7)$ \\
\hline \multicolumn{4}{|l|}{ Mode of delivery } \\
\hline Normal & $50(79.4)$ & $57(78.1)$ & $107(78.7)$ \\
\hline Caesarean section & $12(19)$ & $15(20.5)$ & $27(19.8)$ \\
\hline Assisted & $1(1.6)$ & $1(1.4)$ & $2(1.5)$ \\
\hline \multicolumn{4}{|c|}{ Birth weight (in grams) } \\
\hline $1500-2499$ & 0 & $3(4.1)$ & $3(2.2)$ \\
\hline$\geq 2500$ & $63(100)$ & $70(95.9)$ & $133(97.8)$ \\
\hline
\end{tabular}

(Figures in parenthesis indicate percentages)

*For mothers having children 2 or more than 2

Table 3: Birth history of new-borns $(\mathrm{N}=136)$

were graduate. Out of 136 mothers, 114 (83.8\%) were housewives.

Family background of the study newborns is shown in Table 2. It was observed that parents of $16(11.8 \%)$ newborns had history of consanguineous marriage. The mean age for marriage of mothers of study newborn was $21.9 \pm 3.1$ years. Out of 136 newborns, $73(53.7 \%)$ belonged to nuclear families. Only $22(16.2 \%)$ mothers had more than two living children.

It was observed that, out of 136 newborns, one male child was delivered at home by a trained dai while remaining 135(99.3\%) were delivered at institution by doctor/nurse/ANM. Only three $(2.2 \%)$ female newborns were found to have low birth weight $(<2500 \mathrm{gm})$. There was no significant difference found between male and female newborns in terms of history of birth in this present study (Table 3 ).

It was observed that, out of 136 newborns, 128 (94.1\%) were wrapped immediately after birth. Total 19 (14\%) children had a history of application over umbilical cord by sweet flag (vasambu) 
(52.6\%), oil (42.1\%) or ghee (5.3\%). In the present study, bathing of $96(70.6 \%)$ newborns was delayed till third day or more. However, seven $(5.1 \%)$ newborns were bathed on the first day of birth itself. There was significant difference between male and female newborns in terms of wrapping after birth and day of first bath ( $\mathrm{p}$ value 0.04 and 0.007 respectively). However, no significant difference was observed between male and female newborns as far as cloth used for wrapping, application on umbilical cord stump and type of cord application is concerned (Table 4).

Table 5 shows the association of socio-demographic variables of the study children with newborn care practices in the present study. Among the illiterate mothers, 19 (90.5\%) mothers wrapped their newborn after birth, 5 (23.8\%) mother's practiced application on umbilical stump, and $52(71.2 \%)$ mothers gave bath to their newborns on third day or beyond. There were no significant association between newborn care practices and mothers' education.

Out of 37 mothers who belonged to poor socio-economic status, 9 (24.3\%) mothers practiced application on cord. Significant association was observed between application on umbilical stump and socioeconomic status of mothers ( $\mathrm{p}=0.03)$.Majority $(70.6 \%)$ of mothers gave bath to their newborns' on third day or beyond. Seventy four (77.1\%) mothers aged $\leq 22$ years gave bath to their newborns' on third day or beyond. In the present study, mothers age at marriage and day of first bath to newborns' was significantly associated $(\mathrm{p}=0.02)$. However, no significant association was observed between newborn care practices and mothers occupation, type of family and birth order of newborn in the present study (Table 5).

\section{Discussion}

The present study aimed at assessing the newborn care practices in a rural area of Puducherry. This study described the essential newborn care given during birth examined their association with sociodemographic variables.

According to Census 2011 [7] 80\% males and 79\% females are literate. In the present study, majority $(67.6 \%)$ of the mothers were educated upto 12 th standard and $26.5 \%$ mothers were graduate; this shows that female literacy rate is high in the study area. Out of total women, $83.8 \%$ were housewives and only $11 \%$ were doing service/ business. It stresses the fact that women at a larger scale are still working within the household.

The institutional delivery rate is extremely low at national level. Unless the pace of change accelerates, it will take until 2025 for half of all rural births to be institutional and mid-century before $75 \%$ coverage is reached [8]. There was a slow increase in institutional delivery rate in India, without the sign of acceleration in achieving the national goal of $80 \%$ coverage in 2015 [8]. In present study, $99.3 \%$ deliveries were conducted in institutions and only one $(0.7 \%)$ woman delivered at home by a trained dai due to delay in accessing the nearby health facility. Similar finding was reported in District Level Household Survey-3 (DLHS-3) conducted in Pondicherry with institutional delivery rate of $99.4 \%$ and in Tamil Nadu with $94 \%$ [8].

In contrast, according to DLHS-3 [8], the institutional delivery rate in India was $47 \%$ and as per National Family Household Survey-3 (NFHS-3) for rural areas in India, the rate was 31.1\% [9]. Studies conducted in other states also showed lower level of institutional delivery compared to our study [10-12]. This suggests, there was an effective health education given to women regarding the place of delivery during antenatal visits, availability of facilities and good transport in present study area.

According to the present study, mode of delivery was observed to be normal vaginal delivery (78.7\%). The percentage of mothers who had caesarean section was $19.8 \%$ which was higher as compared to the NFHS-3 report for India (7\%) [9]. Similar observations were noted in studies conducted in Gujarat (15.3\%) and Haryana (16\%) $[10,11]$. The reason for increased caesarean section in the study area was due to increased awareness and readiness towards complications related to delivery among the mothers and their families.

As per Integrated Management of Neonatal and Childhood Illness Guidelines, the newborn should be quickly dried and wrapped in the warm and clean cloth immediately after delivery to prevent heat loss from the body [13]. In the present study, it was observed that, $94.1 \%$ newborns were wrapped immediately after birth. Similar observations were reported from Chandigarh [14], Bangalore [15] as well as from South Nepal [16] with of $93.8 \%, 90.1 \%$ and $82.8 \%$ new-borns respectively being wrapped immediately after birth.

\begin{tabular}{|c|c|c|c|c|}
\hline Indicators & $\begin{array}{l}\text { Male } \\
(n=63)\end{array}$ & $\begin{array}{c}\text { Female } \\
(n=73)\end{array}$ & Total & $\mathrm{p}$ value \\
\hline \multicolumn{4}{|l|}{ Wrapping immediately after birth } & \multirow[t]{3}{*}{0.04} \\
\hline Yes & $62(98.4)$ & $66(90.4)$ & $128(94.1)$ & \\
\hline No & $1(1.6)$ & $7(9.6)$ & $8(5.9)$ & \\
\hline \multicolumn{4}{|l|}{ Cloth used for wrapping $(n=128)$} & \multirow[t]{3}{*}{0.13} \\
\hline New/ washed & $53(85.5)$ & $55(83.3)$ & $108(84.4)$ & \\
\hline Not properly washed & $9(14.5)$ & $11(16.7)$ & $20(15.6)$ & \\
\hline \multicolumn{4}{|l|}{ Application on umbilical cord } & \multirow[t]{3}{*}{0.16} \\
\hline Yes & $6(9.5)$ & $13(17.8)$ & $19(14)$ & \\
\hline No & $57(90.5)$ & $60(82.2)$ & $117(86)$ & \\
\hline \multicolumn{4}{|l|}{ Type of cord application $(n=19)$} & \multirow[t]{4}{*}{0.26} \\
\hline Sweet flag (Vasambu) & $2(33.3)$ & $8(61.5)$ & $10(52.6)$ & \\
\hline Oil & $4(66.7)$ & $4(30.8)$ & $8(42.1)$ & \\
\hline Ghee & 0 & $1(7.7)$ & $1(5.3)$ & \\
\hline \multicolumn{4}{|l|}{ Day of first bath } & \multirow[t]{4}{*}{0.007} \\
\hline $1^{\text {st }}$ day & $2(3.2)$ & $5(6.8)$ & $7(5.1)$ & \\
\hline $2^{\text {nd }}$ day & $23(36.5)$ & $10(13.7)$ & $33(24.3)$ & \\
\hline$\geq 3^{\text {rd }}$ day & $38(60.3)$ & $58(79.5)$ & $96(70.6)$ & \\
\hline
\end{tabular}

(Figures in parenthesis indicate percentages) 
Citation: Vijayalakshmi S, Patil R, Datta SS (2014) Community-based Study on Newborn Care Practices and its Determinants in Rural Pondicherry, India. J Neonatal Biol 3: 158. doi:10.4172/2167-0897.1000158

Pge 4 of 5

\begin{tabular}{|c|c|c|c|c|c|c|c|c|c|}
\hline \multirow[t]{2}{*}{ New-born care practices } & \multicolumn{3}{|c|}{ Mothers' education } & \multicolumn{3}{|c|}{ Mothers' Occupation } & \multicolumn{3}{|c|}{ Socio-economic status } \\
\hline & $\begin{array}{c}\text { Illiterate } \\
(n=21)\end{array}$ & $\begin{array}{l}\text { Literate } \\
(n=115)\end{array}$ & $p$ value & $\begin{array}{c}\text { Housewife } \\
(n=114)\end{array}$ & $\begin{array}{c}\text { Working } \\
(n=22)\end{array}$ & $\mathrm{p}$ value & $\begin{array}{l}\text { Poor } \\
(n=37)\end{array}$ & $\begin{array}{c}\text { Middle/High } \\
(\mathrm{n}=99)\end{array}$ & $p$ value \\
\hline $\begin{array}{l}\text { Wrapping after birth } \\
\text { Yes } \\
\text { No }\end{array}$ & $\begin{array}{c}19(90.5) \\
2(9.5)\end{array}$ & $\begin{array}{c}109(94.8) \\
6(5.2)\end{array}$ & 0.44 & $\begin{array}{c}107(93.9) \\
7(6.1)\end{array}$ & $\begin{array}{c}21(95.5) \\
1(4.5)\end{array}$ & 0.77 & $\begin{array}{c}35(94.6) \\
2(5.4)\end{array}$ & $\begin{array}{c}93(93.9) \\
6(6.1)\end{array}$ & 0.88 \\
\hline $\begin{array}{l}\text { Application on umbilical stump } \\
\text { Yes } \\
\text { No }\end{array}$ & $\begin{array}{c}5(23.8) \\
16(76.2)\end{array}$ & $\begin{array}{c}14(12.2) \\
101(87.8)\end{array}$ & 0.15 & $\begin{array}{l}16(14) \\
98(86)\end{array}$ & $\begin{array}{c}3(13.6) \\
19(83.4)\end{array}$ & 0.96 & $\begin{array}{c}9(24.3) \\
28(75.7)\end{array}$ & $\begin{array}{l}10(10.1) \\
89(89.9)\end{array}$ & 0.03 \\
\hline $\begin{array}{l}\text { First bath given on } \\
1^{\text {st }} \text { Day } \\
2^{\text {nd }} \text { Day } \\
\geq 3^{\text {rd }} \text { Day }\end{array}$ & $\begin{array}{c}1(4.8) \\
4(19) \\
16(76.2)\end{array}$ & $\begin{array}{c}6(5.2) \\
29(25.2) \\
80(69.6)\end{array}$ & 0.82 & $\begin{array}{c}5(4.4) \\
28(24.6) \\
81(71)\end{array}$ & $\begin{array}{c}2(9.1) \\
5(22.7) \\
15(68.2)\end{array}$ & 0.65 & $\begin{array}{c}0 \\
7(18.9) \\
30(81.1)\end{array}$ & $\begin{array}{c}7(7.1) \\
26(26.3) \\
66(66.6)\end{array}$ & 0.13 \\
\hline \multirow[t]{2}{*}{ New-born care practices } & \multicolumn{3}{|c|}{ Type of family } & \multicolumn{3}{|c|}{ Birth order } & \multicolumn{3}{|c|}{ Mothers age at marriage } \\
\hline & $\begin{array}{c}\text { Nuclear } \\
(n=73)\end{array}$ & $\begin{array}{c}\text { Joint } \\
(n=63)\end{array}$ & $p$ value & $\begin{array}{c}1 \\
(n=58)\end{array}$ & $\begin{array}{c}\geq 2 \\
(n=78)\end{array}$ & $p$ value & $\begin{array}{c}\leq 22 \\
(n=96)\end{array}$ & $\begin{array}{c}>22 \\
(n=40)\end{array}$ & $\mathrm{p}$ value \\
\hline $\begin{array}{l}\text { Wrapping after birth } \\
\text { Yes } \\
\text { No }\end{array}$ & $\begin{array}{c}70(95.9) \\
3(4.1)\end{array}$ & $\begin{array}{c}58(92) \\
5(8)\end{array}$ & 0.34 & $\begin{array}{c}56(96.6) \\
2(3.4)\end{array}$ & $\begin{array}{c}72(92.3) \\
6(7.7)\end{array}$ & 0.29 & $\begin{array}{c}91(94.8) \\
5(5.2)\end{array}$ & $\begin{array}{c}37(92.5) \\
(7.5)\end{array}$ & 0.60 \\
\hline $\begin{array}{l}\text { Application on umbilical stump } \\
\text { Yes } \\
\text { No }\end{array}$ & $\begin{array}{l}12(16.4) \\
61(83.6)\end{array}$ & $\begin{array}{c}7(11.1) \\
56(88.9)\end{array}$ & 0.37 & $\begin{array}{c}6(10.3) \\
52(89.7)\end{array}$ & $\begin{array}{l}13(16.7) \\
65(83.3)\end{array}$ & 0.29 & $\begin{array}{l}16(16.7) \\
80(83.3)\end{array}$ & $\begin{array}{c}3(7.5) \\
37(92.5)\end{array}$ & 0.16 \\
\hline $\begin{array}{l}\text { Day of first bath } \\
1^{\text {st }} \text { Day } \\
2^{\text {nd }} \text { Day } \\
\geq 3^{\text {rd }} \text { Day }\end{array}$ & $\begin{array}{c}5(6.9) \\
16(21.9) \\
52(71.2)\end{array}$ & $\begin{array}{c}2(3.2) \\
17(27) \\
44(69.8)\end{array}$ & 0.53 & $\begin{array}{c}1(1.7) \\
15(25.9) \\
42(72.4)\end{array}$ & $\begin{array}{c}6(7.7) \\
18(23.1) \\
54(69.2)\end{array}$ & 0.29 & $\begin{array}{c}3(3.1) \\
19(19.8) \\
74(77.1)\end{array}$ & $\begin{array}{l}4(10) \\
14(35) \\
22(55)\end{array}$ & 0.02 \\
\hline
\end{tabular}

Table 5: Association of socio-demographic variables and newborn care practices $(\mathrm{N}=136)$.

Application on umbilical cord of newborn is a custom followed in many parts of India and majority of them use cow dung as the application which is a common cause of neonatal tetanus and neonatal death. Our study reported that $14 \%$ children had a history of application over umbilical cord stump, either by sweet flag (52.6\%), oil (42.1\%) or ghee (5.3\%). Other studies also reported similar practices of application on umbilical cord, the percentages ranged from $10 \%$ to $50 \%$ [12,17-20]. Common applicant used were turmeric powder, oil and ghee with the percentage of $83 \%, 15.8 \%$ and $12 \%$ respectively $[12,17,19]$.

In the present study, significant association was observed between socio- economic status and application on umbilical cord. Mothers who belonged to poor class practiced application on umbilical cord stump as compared to middle/high class mothers.

According to WHO and UNICEF report on newborn care, bathing should be avoided immediately after birth in order to prevent hypothermia and for a normal newborn bathing should be started on second day [13]. There is a common belief of people that the mother and her newborn are polluted due to the delivery process, so bath should be given immediately after birth [21]. In the present study, bathing of $(70.6 \%)$ infants was delayed till third day or more. However, $5.1 \%$ infants were bathed on the first day of birth itself. In contrary, studied conducted in Bangladesh, Uttar Pradesh, Haryana, Chandigarh and West Bengal reported that $76.1 \%, 67 \%, 56.5 \%, 40 \%$ and $17.6 \%$ infants respectively were given first bath immediately after birth $[19,22,23]$.

Pre-lacteal feeding is almost universal in India. Present study observed that percentage of newborns who were given pre-lacteal feed was only $5.9 \%$. Among them $62.5 \%$ were given animal's milk as prelacteal feed and $37.5 \%$ new-borns were given honey water. Studies from South Nepal [16] and Pakistan [17] reported that the percentage of newborns that were given pre-lacteal feeds was $44 \%, 55.6 \%$ and $87.6 \%$ respectively, which were higher compared to the present study. Studies from other parts of India also reported the practice of giving prelacteal feeds $[15,20,24,25]$.

Colostrum is a thick, yellow secretion from the breast during initial two to three days after delivery. It provides a concentrated source of energy for the newborn which is easily digestible and also offers protection against childhood illnesses. In the present study, $2.2 \%$ newborns did not receive colostrum even after two days of birth. Similar observations were reported from two studies conducted in Bangalore [15,20]. However, studies from other regions of India and other countries also showed even higher percentage of mothers discarding colostrum for first two days [12,15,24,26].

According to Infant and Young Child Feeding Practices (2006) guidelines in India, it is recommended that initiation of breastfeeding should begin immediately after birth. In the present study initiation of breastfeeding within one hour after birth was $64.7 \%$ and within 24 hours was almost $97 \%$. Initiating breastfeeding within one hour was similar to DLHS-3 [8] findings for Pondicherry rural area (67.2\%) and other studies conducted in Uttar Pradesh and rural wardha [12,25]. However, our observations are more than the national and Tamil Nadu figures as per DLHS-3 [8] and NFHS-3 [9]. Mothers belonging to high socio-economic class families had better knowledge related to initiation of breastfeeding. Findings in regard to initiation of breastfeeding in the present study was higher than studies reported from other states of the country and this could be attributed to high level of female literacy, effective antenatal advices to mothers and frequent postnatal visits by healthcare providers leading to increased knowledge regarding early initiation of breastfeeding and the importance of colostrum.

IMNCI recommends on-demand breastfeeding or feeding 8 times or beyond to the newborn [13]. In the present study it was observed that, majority of the mothers breastfed their newborns on demand (80.1\%), similar to the observations made by Joseph et al. [15] in Bangalore (87\%).

\section{Conclusions}

On the whole, the results of our study indicated that most of the mothers were having good child care practices. Practices like giving pre-lacteal feeds, application of substances on the cord, giving bath to the baby immediately after birth are less prevalent in our study. Even 
Citation: Vijayalakshmi S, Patil R, Datta SS (2014) Community-based Study on Newborn Care Practices and its Determinants in Rural Pondicherry, India. J Neonatal Biol 3: 158. doi:10.4172/2167-0897.1000158

Pge 5 of 5

though the overall practices like giving pre-lacteal feed; application on umbilical cord and giving bath immediately after bath of newborn are still practiced in the study area. The present scenario can be improved through enhancing Information Education and Counselling activities, training of health workers and mothers focusing on newborn health care practices.

\section{Strengths}

This was a community based, house to house survey done to know the traditional newborn care practices prevailing in the community. Therefore, faulty newborn care practices are addressed to improve the health status of the newborn. To reduce recall bias due to time delay, the information regarding birth was obtained from discharge slip and other details were cross checked with their husband.

\section{Limitations}

This study focused mainly few determinants that determine newborn care practices. Further study need to be done to provoke the reason for the faulty practices prevailed in the community.

\section{References}

1. Park K (2013) Park's Textbook of Preventive and Social Medicine. (22ndedtn). Banarsidas Bhanot, Jabalpur, India.

2. UNICEF (1979) Year of the child UNICEF. New York, USA.

3. WHO (2013) The World Health Day themes. Geneva, Switzerland.

4. WHO (2011) Neonatal mortality rate. Geneva, Switzerland.

5. NRHM (2012) Special initiatives in India. New Delhi, India

6. Sharma R (2013) Revision of Prasad's social classification and provision of an online tool for real-time updating. South Asian J Cancer 2: 244

7. Government of India (2011) Provisional Population Totals: Office of the Registrar General and Census Commissioner, India.

8. International Institute for Population Sciences (2008) District Level Household and Facility Survey-3. Mumbai, India.

9. International Institute for Population Sciences, Macro International (2006) National Family Health Survey-3. Mumbai, India.

10. Bhanderi DJ, Mukherjee SM, Gohel MK, Christian DS (2009) An evaluation of the utilisation of reproductive and child health services provided by government to the rural community of Anand District, Gujarat. Indian J Public Health 53: 250-252.
11. Anita $P, R b$ J, MS P, Vidya R, K M (2010) Pattern of deliveries in rural areas of a district in Haryana 9: 2-4

12. Thakur N, Kumar A (2012) A study on delivery and newborn care practices in urban slums. Antrocom online $\mathrm{J}$ of Anthropology 8: 1.

13. UNICEF (2011) Integrated Management of Neonatal and Childhood IIIness Government of India, India.

14. Puri S, Bhatia V, Sharma M, Swami HM, Magnat C (2008) Comparison of prevalent newborn rearing practices in urban and slum population. Internet $\mathrm{J}$ Pediatr Neonatol 9:1.

15. Joseph N, Unnikrishnan B, Naik VA, Mahantshetti NS, Mallapur MD, et al. (2013) Infant rearing practices in South India: A Longitudinal study. J Fam Med and Pri Care 2: 37-45.

16. Karas DJ, Mullany LC, Katz J, Khatry SK, LeClerq SC, et al. (2012) Home care practices for newborns in rural southern Nepal during the first 2 weeks of life. J Trop Pediatr 58: 200-207.

17. Khadduri R, Marsh DR, Rasmussen B, Bari A, Nazir R, et al. (2008) Household knowledge and practices of newborn and maternal health 28: 182-187.

18. Agrawal PK, Agrawal S, Mullany LC, Darmstadt GL, Kumar V, et al. (2012) Clean cord care practices and neonatal mortality: evidence from rural Uttar Pradesh 66: 755-758.

19. Baqui AH, Williams EK, Darmstadt GL, Kumar V, Kiran TU, et al. (2007) Newborn care in rural Uttar Pradesh J Pediatr 74: 241-247.

20. Kumar N, Unnikrishnan B, Rekha T, Mithra P, Kulkarni V, et al. (2012) Infant feeding and rearing practices adapted by mothers in coastal South India. Indian J Colla Res Int Med and Publ. Health 4: 1-12.

21. Winch PJ, Alam MA, Akther A (2005) Local understandings of vulnerability and protection during the neonatal period 366 : 478-485.

22. Upadhyay RP, Rai SK, Anand K (2012) Community neonatal practices and its association with skilled birth attendance in rural Haryana 101: 535-539.

23. Alam MA, Ali NA, Sultana N (2008) Newborn umbilical cord and skin care Implications for the promotion of Umbilical cord cleansing with topical chlorhexidine 28: 61-68.

24. Madhu K, Chowdary S, Masthi R (2009) Breast Feeding Practices and Newborn Care Practices in a Rural Block of West Bengal 34: 243-246.

25. Das P, Ghosh S, Ghosh M, Mandal A (2008) A study on delivery and newborn care practices in a rural block of West Bengal. Indian J Public Health 52: 159 160.

26. Bang AT, Bang RA, Baitule S, Deshmukh M, Reddy H (2001) Study on burden of morbidities and unmet need for health care in rural neonates 38: 956-965. 